\title{
Future events and their impact on financial management in the US lodging industry: Delphi study to predict changes in 2007 and 2027
}

Recerved: 23 November 2004

\begin{abstract}
A. J. Singh
is the International Lodging Operations and Real Estate Finance Professor in the School of Hospitality Business at Michigan State University. Dr Singh's goal is to establish the school as the leading solution provider for issues and problems related to international lodging operations, investments and real estate finance. Dr Singh's hospitality experience includes various management positions, academic assignments and consulting activities in the USA, India and Europe.
\end{abstract}

\section{Raymond S. Schmidgall}

is a financial management expert, and the author of Financial Management for the Hospitality Industry. He serves on the industry committees of the Hospitality Financial and Technology Professionals and the American Hotel and Lodging Association.

\begin{abstract}
This paper is one result of a comprehensive Delphi study conducted by the faculty at the School of Hospitality Business at Michigan State University. The purpose of the research was to make predictions in five areas of concern to hospitality industry managers, investors, lenders, educators and others associated with the US lodging industry. One of the prediction areas included finance and financial management in the hospitality industry. The paper presents the historical context, and predicts key events and their impact on future hotel investments; sources and lending terms of lodging capital; capital flows to finance lodging; and management of profits and operational efficiency in the years 2007 and 2027. The industry and management implications are discussed.
\end{abstract}

\section{Keywords:}

Delphi study, financial management, hotel investment, sources of capital, capital flows

A. 1. Singh

School of Hospitality Business 232 Eppley Center Michigan State University East Lansing, MI 48824, USA

Tel: +1 5173539211

Fax: +15174321170

E-mail: singharj@msu.edu

\section{INTRODUCTION AND STUDY CONTEXT}

Hospitality managers, investors, lenders and other decision makers in the hospitality industry are not comfortable with uncertainties and the associated risks that they imply. Most decision makers have some feeling about the occurrence of future events. These may 
range from a high degree of confidence to a vague and ill-defined feeling of discomfort. ${ }^{1}$ Nevertheless, decision makers in the hospitality industry are concerned about the direction of actual change in any future event. Sinkley states that actual change, which is after-the-fact future change, can be broken down into an anticipated component and an unanticipated component. If change consisted of only an anticipated component, there would be little or no risk involved. The unanticipated component is clearly the source of risk. $^{2}$

Through a study of the literature and discussions with hospitality business faculty and industry executives, the following five categories of uncertainties were identified as primary concerns for the hospitality industry:

- the size and structure of the hospitality industry

- management of human resources in the hospitality industry

- management of operations and information technology

-_ marketing management

- financial management.

The purpose of the current study was to identify and predict the likely occurrence of key events that will affect finance and financial management in the lodging industry in 2007 and 2027. By successfully predicting the likelihood with which these key future events will occur, it is hoped to mitigate some of the uncertainty associated with the financial management of lodging organisations in the future and anticipate its financial structure.

\section{OVERVIEW OF THE DELPHI STUDY AND METHODOLOGY}

There are primarily two types of forecasting methods: quantitative

Expert opinion of future and qualitative. Quantitative approaches may be further divided into causal and time series. Causal methods such as regression analysis and econometrics 'assume that the value of a certain variable is a function of other variables'. ${ }^{3}$ Time-series analysis, on the other hand, uses the occurrence of a past pattern to predict future events. Naïve methods, moving averages and exponential smoothing are some examples of time-series analyses.

Certain forecasting problems are not readily handled using a quantitative approach. In such cases one has to rely on qualitative forecasting methods, which are holistic in nature and rely more on human judgment when used to make predictions. One such qualitative (long-term) forecasting technique is the Delphi technique.

'The Delphi technique is a method used to systematically combine expert knowledge and opinion to arrive at an informed group consensus abcut the likely occurrence of future events. ${ }^{4}$

Helmer and Rescher, the original proponents of the Delphi 


\section{Delphi preferred approach for multi- dimensional predictions}

technique, state that 'the technique derives its importance from the realization that projections of future events, on which decisions must often be based, are formed largely through the insight of informed individuals, rather than through predictions derived from well-established theory'.

According to Linstone and Turoff, the Delphi technique should be used when one or more of the following properties exist in the problem. ${ }^{6}$

- The problem does not lend itself to precise analytical techniques but can benefit from subjective judgment on a collective basis

- The individuals needed to contribute to the examination of a broad or complex problem have no history of adequate communication and may represent diverse backgrounds with respect to experience or expertise.

- More individuals are needed than can effectively interact in a face-to-face exchange.

- Time and cost make frequent group meetings infeasible.

- The heterogeneity of the participants must be preserved to assure the validity of the results; ie the participants must not be dominated by quantity or by strength of personality (called the 'bandwagon effect' and the 'halo effect', respectively).

- When the anonymity of the participants is important.

In addition to the above factors, Paliwoda states that when studies involve 'multiple dimensions', a Delphi study may be the preferred choice. ${ }^{7}$ Johnson states that the Delphi technique is especially suited for long-term forecasts - more than five years out in rapidly changing, volatile fields. ${ }^{8}$

All of these reasons had some impact on why the Delphi technique was selected as the method of choice for the present forecasting problem. Most important, however, was that the problem was multi-dimensional in nature and involved expertise, such that no individual had sufficient knowledge to affect a solution. Therefore, the problem required a group decision-making method. The traditional, face-to-face group decision-making processes would have inserted a study bias, however (particularly due to the 'bandwagon effect' and the 'halo effect').

The steps in conducting a Delphi study listed below are combined from various sources in the Delphi literature. ${ }^{9-14}$

- Step 1: Identify the basic issues, problems and events to be predicted.

- Step 2: Select a panel of experts

- Step 3: Explore, discuss and finalise the basic issues and events to be predicted.

- Step 4: Design a draft questionnaire.

- Step 5: Pilot test the draft questionnaire.

- Step 6: Mail Round 1 of the Delphi questionnaire. 
- Step 7: Summarise the statistical results of Round 1 and include these results with the Round 2 mailing of the questionnaire.

- Step 8: Continue future rounds similar to steps 6 and 7.

- Step 9: Analyse the data to show consensus of participants over progressive rounds.

Using faculty and industry expertise, 22 event statements related to finance and financial management for the lodging industry were developed for the questionnaire. Each event statement was assigned a five-point likelihood of occurrence scale with 5 indicating 'very likely to occur' and 1 indicating 'not likely to occur'. The questionnaire was divided into two prediction periods: 2007 (near term) and 2027 (long term). Space was also provided at the end of the questionnaire for respondents to write open-ended predictions about key events, issues and trends that would influence financing of the lodging industry in the future.

An expert for the purposes of the study was expected to have a broad understanding of their industry sector, with specific expertise in at least one functional area. The expert was to be either in a top management position or a hotel owner, and directly involved in making strategic decisions for their organisation. Finally, it was felt that an effective panel of experts should not only be accessible but also interested in the results of the research.

The School of Hospitality Business at Michigan State University's alumni database provided a rich list for the selection of the expert panel. Seventy-four lodging executives were selected as experts using the above criteria. Table 1 illustrates the profile of the expert panel that participated in the study.

\section{FUTURE EVENTS AND THEIR IMPACT ON LODGING FINANCE}

The key finance and financial management event predictions made by the experts are summarised into four broad areas:

- events impacting on hotel investments in the future (Table 3)

- sources and lending terms of lodging capital in the future (Table 6)

- capital flows to the lodging industry in the future (Table 8)

- events impacting on profits and operational efficiency in the future (Table 10).

Table I: Profile of Delphi expert pane

\begin{tabular}{lll}
\hline Panel expertise & $\begin{array}{l}\text { Round I } \\
\text { respondents }\end{array}$ & $\begin{array}{l}\text { Round } 2 \\
\text { respondents } \\
\mathbf{N}\end{array}$ \\
\hline $\begin{array}{l}\text { Presidents and CEOs, vice presidents, owners, general managers and senıor hotel } \\
\text { development executives with major US and international hotel companies } \\
\text { Of the original } 74 \text { questionnaires malled }\end{array}$ & 38 & 25 \\
\hline
\end{tabular}


Investors pessimistic about growth in future returns
Each of these predicted events has an assigned probability of occurrence in the near-term (2007) and long-term (2027) future, and is analysed in the context of the past and present scenarios. Finally, the implications of these predictions for the lodging industry and lodging industry finance are discussed.

\section{Events impacting on hotel investments in the future}

Individuals and institutions investing in hotel real estate are driven by different objectives in their decision. At the very least, they expect their investment to provide returns to cover inflation and compensate them for the associated risks. ${ }^{15}$ In order to achieve those objectives, investors need to understand the role of market cycles in timing their investment, maximise income from operations and have an exit strategy for their hotel investment. A clear understanding of these dynamics will optimise total returns: a combination of capital appreciation and income return.

Three predictions made by the Delphi panellists, both in the short term (2007) and long term (2027), project a pessimistic future scenario in terms of the cost of hotel real estate ownership and consequent capital flows to the industry. These predictions indicate that investors may be more challenged to achieve higher returns in the future, and investment capital flowing to hotels may be reduced.

First, most respondents ( 84 per cent) believe that the cost of real estate will be higher in 2007 as prime locations become less available. An even greater percentage of respondents (96 per cent) believe this will be true by 2027 . As the supply of land is fixed and as the population continues to increase, it is a fair assumption that commercially viable real estate will become scarce. As such, the cost of real estate realistically can be expected to increase. These predictions are supported by an investor survey conducted by Lend Lease, a company specialising in real estate (Table 2). Their 2003 report on emerging trends in real estate predicts a 12 per cent change in full-service hotel values in the next five years and 22.3 per cent over a ten-year period. The same report predicts a 10.6 per cent change in limited service hotel values over the next five years

Table 2: Change in investment property values

\begin{tabular}{lll}
\hline Property type & $\begin{array}{l}\text { Five-year } \\
\text { prediction } \\
\text { (\%) }\end{array}$ & $\begin{array}{l}\text { Ten-year } \\
\text { prediction } \\
\text { (\%) }\end{array}$ \\
\hline Apartments & 146 & 28.5 \\
Warehouses & 12.8 & 22.6 \\
Community shopping centres & 12.6 & 22.4 \\
Downtown offices & 12.2 & 24.5 \\
Full-service hotels & 12.1 & 223 \\
Regional malls & 11.2 & 19.9 \\
Suburban offices & 10.9 & 21.9 \\
Limited-service hotels & 10.2 & 18.3 \\
Research and development & 9.8 & 17.6 \\
Power centres & 8.5 & 15.9 \\
\hline
\end{tabular}


and 18.3 per cent in ten years. ${ }^{16}$ Implicit in these predictions of value appreciation is the underlying price of real estate.

Following their first prediction of the increasing cost of owning hotel real estate, panellists further predicted that higher initial (real estate) and ongoing operating costs will dampen interest in hotel investments by private investors. Sixty per cent of the panellists felt that private investors would be less attracted to hotel real estate in 2007 , and a slightly larger proportion of panellists ( 63 per cent) held this view for their long-term (2027) prediction as well.

Building on the two previous predictions, not surprisingly about half ( 52 per cent) of the panellists felt that capital flows to the lodging industry would be reduced in 2007 , as competing investments would attract a larger share of investment capital flows. Fewer ( 38 per cent) of the panellists were certain of this event in their long-term prediction.

The advantage of diversifying an investment portfolio is to reduce non-systematic risk. A variety of factors contribute to nonsystematic risk in real estate investments: lease terms, operating and financial leverage and demand versus supply of space, tenant mix and location. These in turn are affected by business cycles, cost of capital, inflation and economic and demographic trends. ${ }^{17}$ Hotel real estate in the USA alone, for example, represents over US\$100bn of unsecuritised investment-grade properties. ${ }^{18} \mathrm{~A}$ sector

Hotels will remain a non-core part of real estate portfolio of this size suggests that it should be included in a well-diversified portfolio and be present in the minds of institutional real estate investors. Recent surveys of allocations between property types in the investment-grade, commercial-real-estate-only portfolios show that hotels constitute approximately 1.6 per cent of the total allocation. ${ }^{19}$ Due to this small percentage of institutional holding, hotels are categorised as a non-core part of the investor portfolio. Based on the size of the US hotel real estate sector, and the strong correlation between the institutional investor opinion about a particular asset class and the flow of capital to that asset class (hotels for instance), the researchers were interested in learning if this would continue into the future as well.

Based on the expert panel predictions, the 'non-core' allocation of hotel real estate is expected to continue into the future, with 76 per cent and 75 per cent predicting that this will be the case for the near and long term, respectively. A lack of understanding of the hotel business and its high-risk profile, combined with the dearth of research on the diversification benefits of hotels in an investment portfolio, are the most likely reasons for this marginal role in multiproperty investment portfolios. To address this issue, a research study conducted by Petersen and Singh investigated investment property returns for a 20 -year period, using the semi-annual returns produced by the National Council of Real Estate Investment Fiduciaries (NCREIF) from 1982 to $2001 .^{20}$ The study results supported the diversification benefits of hotels in a multi-property portfolio. These benefits include risk reduction and virtually equal 


\section{Various legislative measures to promote public confidence in investment process}

risk-adjusted returns when hotels are included. While it is not prudent to extend past performance naively to predict future performance, these results make a strong argument for the inclusion of hotels when institutional portfolio managers formulate their diversification strategies.

Over the past 20 years, investor confidence in public companies has ebbed due to a breakdown in corporate governance and adequate government regulations to hold managements and boards of directors accountable for their fiduciary responsibilities to the owners. In the $1980 \mathrm{~s}$, the crisis in confidence was due to abuses of high-yield junk bonds, insider information, the leveraged buyout craze and the savings and loans debacle. Following the stock market crashes in 1987 and 1989, the stage was set for the accounting crisis of the 1990 s, which was characterised by misuse of corporate funds, misrepresentation of true earnings and grossly overcompensated corporate executives. ${ }^{21}$

In 2002, Hospitality Valuation Services (HVS) conducted its annual survey of board performance with 58 public lodging companies. Based on the HVS report, only eight of the 58 boards examined met the criteria for best-performing boards. ${ }^{22}$ Since investor confidence in the integrity of capital markets and the governance of public companies that operate in them directly affects the flow of equity capital to public companies (lodging included), the researchers were interested in predicting the future direction of regulations in this area. Two-thirds of the Delphi panellists were optimistic that increased regulations will transform corporate governance and increase transparency and the independence of corporate boards.

Evidence supports the panellists' predictions, as various measures have been undertaken to instil public confidence into the investment process - the most important of which was the passage of the Sarbanes-Oxley Act of 2002. According to PricewaterhouseCoopers, the Act is 'the single most important piece of legislation affecting corporate governance, financial disclosure and practice of public accounting since the US Securities laws of the 1930s' ${ }^{23}$ Key features of the Act include the establishment of the Public Company Oversight Board to review the audits of public companies. In addition, it focuses on auditor independence, revised standards on public company audit committees, stricter guidelines for issuance of quarterly earnings and annual reports, enhanced financial disclosure, stricter rules for corporate and criminal fraud accountability and enhanced penalties for white-collar crimes. ${ }^{24}$

There is usually a time lag between transitions from enactment of regulations to actual compliance and restructuring of corporate systems. While companies are taking steps to comply with the Act, progress has been slow. As noted in HVS's 2004 survey on board independence, some progress has been made since 2002 but it continued to find board performance lacking. ${ }^{25}$ The biggest 
Table 3: Events impacting on hotel investments in the future (2007 and 2027)

\begin{tabular}{|c|c|c|c|c|c|c|}
\hline & $\begin{array}{l}\text { Mean* } \\
2007\end{array}$ & $\begin{array}{l}\text { Median } \\
2007\end{array}$ & $\begin{array}{l}\text { Event } \\
\text { probability } \\
2007^{* *}(\%)\end{array}$ & $\begin{array}{l}\text { Mean* } \\
2027\end{array}$ & $\begin{array}{l}\text { Median } \\
2027\end{array}$ & $\begin{array}{l}\text { Event } \\
\text { probability } \\
2027^{* *}(\%)\end{array}$ \\
\hline $\begin{array}{l}\text { Cost of real estate will be higher } \\
\text { as prime locations become less } \\
\text { avalable }\end{array}$ & 4.1 & 4.0 & 84 & 4.7 & 5.0 & 96 \\
\hline $\begin{array}{l}\text { Hotels will continue to be a 'non- } \\
\text { core' part of institutional investor } \\
\text { portfolio }\end{array}$ & 3.8 & 4.0 & 76 & 3.8 & 4.0 & 75 \\
\hline $\begin{array}{l}\text { Government regulations will } \\
\text { transform corporate governance, } \\
\text { requiring more definition and } \\
\text { legislating better board } \\
\text { independence }\end{array}$ & 3.7 & 40 & 64 & 3.8 & 4.0 & 67 \\
\hline $\begin{array}{l}\text { Private investors will find hotel } \\
\text { investments unattractive, with } \\
\text { higher start-up and operating } \\
\text { costs }\end{array}$ & 3.6 & 4.0 & 60 & 3.6 & 4.0 & 63 \\
\hline $\begin{array}{l}\text { Capital flows to the lodging } \\
\text { industry will be reduced as } \\
\text { opportunities for alternative } \\
\text { investments increase }\end{array}$ & 3.5 & 40 & 52 & 3.4 & 3.0 & 38 \\
\hline $\begin{array}{l}\text { Increasingly, public companies will } \\
\text { go private to escape scrutiny from } \\
\text { analysts, government and investors }\end{array}$ & 2.8 & 3.0 & 20 & 2.8 & 3.0 & 13 \\
\hline
\end{tabular}

* Scale: 5 = Very likely to occur; 1 = Not at all likely to occur

${ }^{* *}$ Cumulative percentage of 'Very likely to occur (5)' and 'Likely to occur (4)'

\section{Lending terms and criteria affect access to capital}

improvement since 2002 was in the committee structure of the boards. In particular, the audit committee in most of the surveyed companies had been overhauled, presumably in response to Sarbanes-Oxley. As these perceived and real conflicts of interest are removed or closely monitored, public confidence in corporate integrity is expected to improve.

\section{Sources and lending terms of lodging capital in the future}

The structure of a loan made by a lender is a function of six interrelated elements (criteria and terms): the debt-coverage ratio, loan-to-value ratio (LTV), loan term, amortisation period, interest rate and size of loan. The overall economic environment, the Federal Reserve's monetary policy, the regulatory environment of financial institutions and the performance of the industry or company to which the loan is being made generally affect these lending criteria and terms. These lending terms and criteria determine the ability of hotel borrowers to access capital. When conditions are favourable, more borrowers will be able to access loans; when conditions are stringent, the reverse is true. In the early 1980 s lending terms and criteria were relaxed and favoured borrowers, which resulted in an oversupply of 'undisciplined' capital to the lodging industry and led to overbuilding. Because of overbuilding in the lodging and other commercial real estate sectors, lending terms and criteria were tightened from 1990 to 1993, which resulted in a scarcity of capital for lodging investors. 
Table 4: Hotel lending terms (1986-2004)

\begin{tabular}{lrrrrrrrrrrrr}
\hline & 1986 & 1988 & 1990 & 1992 & 1994 & 1995 & 1996 & 1998 & 2000 & $\mathbf{2 0 0 2}$ & $\mathbf{2 0 0 3}$ & 2004 \\
\hline Debt-coverage ratio & 1.30 & 1.30 & 1.30 & 1.60 & 1.40 & 1.38 & 1.40 & 1.38 & 1.41 & 1.52 & 1.47 & 1.47 \\
Interest rate (\%) & 10.10 & 11.60 & 11.50 & 8.90 & 9.90 & 9.59 & 9.10 & 7.65 & 9.21 & 8.25 & 7.72 & 7.08 \\
Loan to value (\%) & 72.50 & 73.60 & 69.00 & 67.40 & 68.00 & 69.12 & 69.70 & 65.33 & 66.41 & 62.17 & 65.25 & 68.96 \\
\hline
\end{tabular}

Source: Hospitaitty Research Group 'Hospitality investment survey', San Francisco, CA, USA.

\section{Lending terms expected to be more rigorous in future}

From 1994 to 2000 , as the hotel industry returned to profitability, access to debt capital improved, but lending terms remained stringent and loans were made to selective and economically viable projects (Table 4). In the past two years LTVs have ranged from 62 to 65 per cent, with relatively low rates of interest. While capital is available to finance hotels, and money rates are at historic lows, lenders remain selective when making hotel loans and require adequate debt coverage and equity participation.

Projecting lender sentiments into the future, 80 per cent of the Delphi panellists maintained that lending terms would be more rigorous for hotel loans in 2007, and 75 per cent agreed with this prediction for 2027 as well.

Commercial banks were the traditional construction lenders to the lodging industry. Typically, financial intermediaries make loans that are compatible with the type of capital they raise. In the case of commercial banks, as most of their liabilities are short term (demand deposits), they prefer short-term construction loans which are paid off at the end of a construction project. ${ }^{26}$ Not surprisingly, the traditional role of banks as construction lenders will continue into the future, with 76 per cent of the panellists supporting this view for the near term and 58 per cent for the long term.

The fixed (and long-term) nature of life insurance company (LIC) sources of funding make LICs ideally suited to provide 'take-out' or permanent financing. After construction is complete, a long period of cash flow begins that is expected to service the loan. Even though LICs reduced permanent lending to hotels during the industry downturn of 1992 and 1993, LIC mortgage holdings have been in the $\$ 200$ bn range, with hotel loans accounting for approximately 3 per cent of LIC mortgage holdings. ${ }^{27}$ While it is true that recently LICs have relied increasingly on commercial mortgage-backed securities (CMBS) as opposed to direct mortgages for their debt exposure, they remain an important source of permanent financing for hotels. The researchers were therefore surprised when a very small percentage ( 16 per cent and 8 per cent respectively) of the Delphi panellists thought that LICs would continue to be the primary source of permanent financing for hotels in the future. It is the researchers' contention that, while contractions in the future are part of the normal cycle, one would expect LICs to remain the key providers of permanent financing for hotels in the future. 


\section{Evolution of securitisation in hotel real estate}

The history of investment banks' involvement with the lodging industry can be traced to the early 1990s, when the Resolution Trust Corporation (RTC) was entrusted with the job of selling defaulted loan portfolios. Investment banks accelerated the process when they began to securitise large portfolios of mortgages and sell them for the RTC. This single act jump-started the commercial mortgage backed securities (CMBS) industry and hastened investment banks' entry into the real estate business. ${ }^{28}$ Having devised a way to securitise commercial real estate, the investment banking community's involvement with financing the lodging industry became easier, particularly when investment banks found that many of the traditional lenders and investors had departed the market and that the lodging industry was in need of capital. Many hotel companies and real estate investment trusts (REITs) raised capital through investment banks in the public capital markets (selling shares to individuals and institutions) to purchase hotel properties that were being sold during the early 1990s at fire-sale prices. This early involvement of investment banks with lodging companies included refinancing their debt in the public markets, structuring initial public offerings (IPOs), financing mergers and acquisitions and underwriting of equity issues of REITs and public hotel companies. Later, as hotel real estate entered the CMBS market, investment banks were involved in underwriting and selling these various debt securities.

From 1992 to 1998, investment banks raised nearly \$14bn in public equity for the lodging industry in the capital markets. ${ }^{29}$ While the pace of public equity offerings slowed from the high of $\$ 5$ bn in 1996, with the growth of securitisation and public hotel companies, investment banks are expected to remain a significant source of capital for the lodging industry in the future. More than half of the Delphi panellists said they would play a larger role in providing capital to the industry in 2007 , and 78 per cent of the panellists held this view for their long-term prediction to 2027 .

With a growing economy and low interest rates there was a strong interest in real estate investments from 1995 to 1998. This period also saw strong growth and maturation of the CMBS market, with a cumulative growth of 183.5 per cent from 1996 to 1998. The CMBS market started to slow down after reaching a market peak in 1998, with a total issuance of $\$ 78 \mathrm{bn}$. From 1996 to 2000 the lodging industry witnessed its strongest performance in terms of demand, revenue and profitability growth, and growth through mergers and acquisitions. Consequently, during the period from 1997 to 1999 the percentage of hotel loans as a component of securitised loans also increased, with a peak in 1998 of 12 per cent (Table 5). ${ }^{30}$

Two issues have affected the current environment of the CMBS marketplace. First, the terrorist attacks on 11 September 2001 accelerated the already weakening economy and real estate markets. Secondly, while the 'event crisis' generated by the attack affected all 
Securitisation will not lower cost of debt
Table 5: Issuance of hotel CMBS (1995-2002)

\begin{tabular}{lll}
\hline Year & $\begin{array}{l}\text { Total hotel issuance } \\
\text { (\$bn) }\end{array}$ & $\begin{array}{l}\text { Hotel CMBS percentage to total } \\
\text { issuance }\end{array}$ \\
\hline 1995 & 0.0 & 0.0 \\
1996 & 0.7 & 2.3 \\
1997 & 0.4 & 9.4 \\
1998 & 9.7 & 12.3 \\
1999 & 6.7 & 9.9 \\
2000 & 4.7 & 7.7 \\
2001 & 5.9 & 6.0 \\
2002 (Q1) & 0.5 & 3.9 \\
\hline
\end{tabular}

Source: Commercial Mortgage Alert, Hoboken, NJ, USA, www.cmalert.com

property types, the effect on certain property types, such as hotels, was much more catastrophic. These two combined effects of the terrorist attacks resulted in a reduction of CMBS issues in 2002, although the market rebounded in 2003 with CMBS debt issuance increasing to over $\$ 98 \mathrm{bn}$. The strong issuance trend continues into 2004 , with total issuance totalling $\$ 85 \mathrm{bn}$ up to the third quarter of that year. ${ }^{31}$

Most Delphi panellists do not believe that the growth of securitisation will lower the cost of debt. In fact only 17 per cent believed this would happen in 2007 and 13 per cent in 2027. This prediction is at odds with the trend in CMBS spreads, which shows that CMBS spreads over ten-year treasury bonds from 1998 to 2004 have continued to reduce, except for the riskiest tranches. ${ }^{32}$

\section{Capital flows to the lodging industry in the future}

During the last 30 years, the need for capital by the industry was determined largely by the stage of the lodging industry's business cycle during each historical period. A cyclical stage in which supply exceeded demand for rooms characteristically resulted in lower property values, which resulted in lower acquisition costs per room. The opposite was the case during the growth or peak stages of the

Table 6: Sources and lending terms of lodging capital in the future (2007 and 2027)

\begin{tabular}{lllllll}
\hline & $\begin{array}{l}\text { Mean* } \\
\mathbf{2 0 0 7}\end{array}$ & $\begin{array}{l}\text { Median } \\
\mathbf{2 0 0 7}\end{array}$ & $\begin{array}{l}\text { Event } \\
\text { probability } \\
\mathbf{2 0 0 7 * *}(\%)\end{array}$ & $\begin{array}{l}\text { Mean* } \\
\mathbf{2 0 2 7}\end{array}$ & $\begin{array}{l}\text { Median } \\
\mathbf{2 0 2 7}\end{array}$ & $\begin{array}{l}\text { Event } \\
\text { probability } \\
\mathbf{2 0 2 7 * *}(\%)\end{array}$ \\
\hline $\begin{array}{l}\text { Banks will remain the primary } \\
\text { source of construction loans }\end{array}$ & 3.8 & 4.0 & 76 & 3.6 & 4.0 & 58 \\
$\begin{array}{l}\text { Lending terms required by } \\
\text { lenders will be more rigorous }\end{array}$ & 4.0 & 4.0 & 80 & 3.8 & 40 & 75 \\
$\begin{array}{l}\text { Investment banks will have a } \\
\text { larger role in providing capital } \\
\text { to the industry }\end{array}$ & 3.5 & 4.0 & 54 & 3.9 & 4.0 & 78 \\
$\begin{array}{l}\text { LICs will remain the primary } \\
\text { source for permanent loans }\end{array}$ & 2.8 & 3.0 & 16 & 2.8 & 3.0 & 8 \\
$\begin{array}{l}\text { Increase in securitisation will } \\
\text { lower cost of debt }\end{array}$ & 2.8 & 3.0 & 17 & 2.8 & 3.0 & 13 \\
\hline
\end{tabular}

* Scale: $5=$ Very likely to occur; $1=$ Not at all likely to occur

${ }^{\star \star}$ Cumulative percentage of 'Very likely to occur (5)' and 'Likely to occur (4)' 
Most future capital flows for acquisition vs construction business cycle. During each historical period, the purpose for which capital was used in the lodging industry also varied. When acquisition costs started to exceed construction costs, more capital was applied towards the construction of hotels; whereas in other periods, when the hotel product was beginning to age, capital was applied towards renovation or conversion.

In a Delphi research study conducted in 1998, the panellists were asked to predict the average selling price and average replacement cost of hotels in $2005 .{ }^{33}$ The results, reported in Table 7 , summarise the predicted ratios of average selling price to average replacement cost of hotel rooms, categorised by tiers, for the year 2005. While Table 7 has specific predictions for the different hotel tiers, the panellists predicted that lower-price hotels would be cheaper to acquire versus new construction. On the other hand, acquisition costs of first-class and luxury hotels are expected to exceed the cost of a new construction in 2005 .

If the predictions of the previously cited Delphi study are assumed to be true, it would explain the panellist predictions in the present study, where 58 per cent felt capital would flow mainly for acquisition in 2007 and the same long-term view on this question was held by 48 per cent of the respondents (Table 8 ). About onethird of the respondents predicted a high likelihood of capital being spent for renovation and updates during the short- and long-term prediction periods. This is in keeping with the view that the lodging product is ageing and many facilities need to be upgraded in order to remain competitive.

The researchers were surprised by an almost unanimous prediction (greater than 90 per cent) by the panellists that debt and equity capital will not flow for hotel construction activities in both predicted years. Historically, most of the hotel supply changes in the long run have been through new construction. Smith Travel Research has tracked room supply growth for 14 years (1987-2001), and showed that the most significant source $(1,583,342$ rooms) of supply growth over this period was from new construction. ${ }^{34}$

The hotel products that attracted capital were also different in different historical periods. In the 1960s, for example, with the growth of franchising (predominately associated with highway properties), the major use of capital was for franchised highway

Table 7: Ratıo of average selling price to average replacement cost of hotels in 2005 (price per room)

\begin{tabular}{ll}
\hline Tiers & Ratio (\%) \\
\hline Budget & 46 \\
Economy: limited service & 70 \\
Economy: full service & 88 \\
Mid-market: limited service & 80 \\
Mid-market: full service & 63 \\
First-class: upscale & 105 \\
Luxury & 150 \\
\hline
\end{tabular}


Acquisitions in urban locations expected to remain popular
Table 8: Capital flow to the lodging industry in the future (2007 and 2027)

\begin{tabular}{lllllll}
\hline & $\begin{array}{l}\text { Mean* } \\
\mathbf{2 0 0 7}\end{array}$ & $\begin{array}{l}\text { Median } \\
\mathbf{2 0 0 7}\end{array}$ & $\begin{array}{l}\text { Event } \\
\text { probability } \\
\mathbf{2 0 0 7 * *} \text { (\%) }\end{array}$ & $\begin{array}{l}\text { Mean* } \\
\mathbf{2 0 2 7}\end{array}$ & $\begin{array}{l}\text { Median } \\
\mathbf{2 0 2 7}\end{array}$ & $\begin{array}{l}\text { Event } \\
\text { probability } \\
\mathbf{2 0 2 7 * *}(\%)\end{array}$ \\
\hline $\begin{array}{c}\text { Equity and debt capital will flow } \\
\text { mainly for acquisition activities } \\
\text { Equity and debt capital will flow }\end{array}$ & 3.6 & 4.0 & 58 & 3.4 & 3.0 & 48 \\
$\begin{array}{l}\text { mainly for renovation and } \\
\text { upgrading }\end{array}$ & 3.4 & 3.0 & 38 & 3.3 & 3.0 & 30 \\
$\begin{array}{c}\text { Equity and debt capital will flow } \\
\text { mainly for construction activities }\end{array}$ & 2.8 & 3.0 & 8 & 3.0 & 3.0 & 9 \\
$\begin{array}{l}\text { Most capital will flow to finance } \\
\text { urban hotels }\end{array}$ & 3.3 & 3.0 & 42 & 3.3 & 3.0 & 48 \\
$\begin{array}{c}\text { Most capital will flow to finance } \\
\text { suburban hoteis }\end{array}$ & 3.1 & 3.0 & 17 & 3.1 & 3.0 & 26 \\
$\begin{array}{c}\text { Most capital will flow to finance } \\
\text { highway hotels }\end{array}$ & 2.1 & 2.0 & 4 & 2.1 & 2.0 & 4 \\
\hline
\end{tabular}

Scale: $5=$ Very likely to occur; $1=$ Not at all likely to occur

** Cumulative percentage of 'Very likely to occur (5)' and 'Likely to occur (4)'

hotels. During the period of suburban growth (the 1960s and 1970s), airport and suburban hotels gained popularity and hotels were not built or acquired in city-centre locations. Table 9 shows the distribution of lodging room supply by location for two time periods: 1990 and 1998. The summary of changes in segmentation by location shows that suburban and highway locations maintained the highest share of hotel rooms in the USA. This is indicative of the move of businesses from central business district locations (CBDs) to the suburbs and the continued use of the automobile by most travellers as the primary travel method. As is noted in Table 9, while suburban locations increased their share slightly over 1990, there have been no dramatic shifts in supply based on location in the past.

While not consistent with the historic trend, 42 per cent of the Delphi panellists in the current study predicted capital flowing for urban hotel projects in 2007, and 48 per cent made this prediction for 2027. This prediction is consistent with one-third of the panel predicting that capital would flow towards renovation projects (most of which tend to be in older urban locations). The current trend towards the 'hot' boutique segment supports this prediction, as many boutiques (such as Kimpton Hotels and Joie De Vivre) tend to be in urban locations and are conversions of existing properties.

Table 9: Segmentation of room supply by location (1990 and 1998)

\begin{tabular}{llccc}
\hline Location & $\begin{array}{l}\text { Total rooms } \\
\text { (1990) }\end{array}$ & $\begin{array}{l}\text { Share of rooms } \\
\text { (\%) }\end{array}$ & $\begin{array}{l}\text { Total rooms } \\
\text { (1998) }\end{array}$ & $\begin{array}{l}\text { Share of rooms } \\
\text { (\%) }\end{array}$ \\
\hline Urban & 485,658 & 15.9 & 535,100 & 14.7 \\
Suburban & 995,675 & 32.7 & $1,273,200$ & 35.0 \\
Airport & 219,310 & 7.1 & 244.300 & 6.7 \\
Highway & 982,946 & 32.2 & $1,164,200$ & 32.0 \\
Resort & 364,679 & 12.0 & 427,700 & 11.7 \\
Total & $3.048,268$ & 100.0 & $3,644,500$ & 100.0 \\
\hline
\end{tabular}

Source: Smith Travel Research, Hendersonville, TN, USA, www.smithtravelresearch.com 
Highway hotel growth reaches plateau

\section{Labour cost remains highest operating cost in hotels}

While historic trends show that suburban hotels have the largest location-based market share, the vast majority of the panellists did not feel that most capital would flow to this segment (17 per cent and 26 per cent supporting this statement for the respective years). Decreasing availability of land and a resulting increase in price, saturation of current demand and weakening of the pace of suburban economic growth may explain these predictions.

Capital flows to highway hotels in the future were seen as even less likely, with almost unanimous agreement ( 96 per cent in both prediction periods) by the panellists that most capital will not flow to this segment. Given the historical context of the segment having reached a plateau (Table 9), this prediction makes sense, although it masks the fact that highway hotels have remained very active in terms of conversions both in and out of the segment. Typically, this location segment consists of economy, midscale with food and beverage and midscale without food and beverage hotels. An analysis of these segments from the supply growth survey conducted by Smith Travel Research ${ }^{35}$ as noted below, shows considerable activity in the 14 years from 1987 to 2001 .

Most of the new construction in this segment was in the midscale without food and beverage hotels $(432,412$ rooms), with more conversions in $(307,668)$ versus out $(278,618)$. On the other hand, midscale properties with food and beverage show declining popularity in terms of both new construction $(128,922)$ and the high number of conversion outs $(1,696,722)$. Finally, new construction in the economy segment was also slow $(365,416)$, but with a larger number of conversions into the segment than out of the segment. ${ }^{35}$

\section{Events impacting on profits and operational efficiency in the future}

Hotels are structurally a labour-intensive business, resulting in historically high labour costs of operation. The total employees-tooccupied-room ratio stood at 78:100 in 1990 and subsequently declined to $72: 100$ in $2000 .^{36}$ Despite this improvement in productivity, hotel payroll taxes and employee benefits were 34.5 per cent of total revenues in 2003, as reported by Pannell Kerr Forster (PKF) in the company's annual report covering the US lodging market. Even though in 2000 and 2001 payroll and related costs reduced to approximately 30 per cent, the average payroll and related costs have remained at around 33 per cent of total revenue for the past 20 years. ${ }^{37}$

Therefore it was not surprising when the panellists nearly unanimously ( 92 per cent) predicted that labour cost will remain one of the highest hotel operating costs in 2007. Their long-term predictions on these two questions evoked the same sentiments, even though fewer ( 84 per cent) panellists felt that these costs would continue to be the highest in $2027 . .^{38}$

In another part of the research study, Delphi panellists predicted 
Telephone departments will become cost centres that hotels will require fewer employees as technology replaces various human functions. ${ }^{39}$ Despite improvements in labour productivity, however, high labour costs are expected to continue into the near and distant future.

In 1981 the Federal Communication Commission permitted hotels to resell interstate calls to hotel guests by levying a surcharge on the cost of calls made from guest rooms. ${ }^{40}$ This launched the era of hotel telephone departments operating as revenue sources and profit centres. In recent years this trend appears to be reversing itself, however. While in 1982 a PKF report indicated that 3 per cent of hotel revenue was derived from telecommunications, the 2003 report shows telecommunication revenues as 1.4 per cent of total hotel revenue. ${ }^{41}$ Various industry reports and articles on the subject point to the use of cellphones as the primary cause of this declining revenue trend. According to Forrester Research, approximately two-thirds of US households have adopted some form of cellphone technology, increasing from approximately 50 per cent in $2000 .^{42}$ If this trend continues, telephone departments will become cost centres, as predicted by the Delphi panellists. A majority ( 85 per cent) predicted this to happen by 2007 , and 84 per cent for 2027.

In June 2004 the US Department of Treasury extended the term of the Terrorism Risk Insurance Act of 2002, which was due to expire in December 2004. The Act, which has been extended until December 2005, requires commercial property and casualty insurers to make terrorism risk insurance available to hotels. In general, the Act ensures that the federal government shares the cost of damages with the insurer once they exceed $\$ 5 \mathrm{~m} .{ }^{43}$ Approximately 60 per cent of the Delphi panellists felt that terrorism risk insurance will be the norm for larger hotels in 2007 , and about 48 per cent predicted the same for 2027.

While insurance companies are required to make insurance available, the Act does not require property casualty companies to make the insurance affordable. The direct effect of this will be higher insurance costs for hotels that choose to purchase this insurance coverage. Insurers claim that the high cost is due to a non-mandatory clause in the Act which does not require the buyers (hotels for example) to purchase insurance. With fewer properties the terrorism risk cannot be efficiently spread, as is the case when a large number of hotels purchase insurance. ${ }^{44}$ Currently, the insurance industry is lobbying to ensure that the Act becomes permanent, and is recommending changes to the Act in order to make it cost-effective for insurance companies to provide coverage.

Computers have become an integral part of both front- and back-office systems, and have evolved from being a business tool to a driver of business processes in a hotel. While the property management systems and related interfaces have improved employee productivity and operational effectiveness, they pose a purchasing challenge because they rapidly become functionally 


\section{Hotel investments will need to provide higher risk adjusted returns in future}

obsolete. The pace at which processing speeds and new applications (wireless for example) are being introduced has put pressure on hotel companies to evaluate their IT capital expenditure practices. Leasing IT equipment is being viewed as an attractive option to keep the technology current. The Delphi panellists were asked to predict if leasing would become the preferred method of financing IT systems in the future. Only about half the respondents felt that leasing will become a popular choice in the future, for both the prediction periods.

\section{SYNTHESIS OF PREDICTIONS AND IMPLICATIONS FOR THE LODGING INDUSTRY}

As the lodging industry is a subset of commercial real estate in general, it competes for capital with the other real estate asset classes. While the Delphi panellist predictions on the higher cost of real estate should impact on all real estate classes, higher risks associated with hotel investments will require the sector to provide higher-risk-adjusted returns in the future in order to maintain investor interest in the industry.

Sophisticated investors will continue to find undervalued hotels, and create value through better management of both revenue and expenses. But, as an industry, hotels continue to be fixed-cost intensive businesses with revenue flows susceptible to external events. In order to remain attractive as an investment class in the future, the industry will have to re-engineer its business practices to produce more stable and predictable revenue flows, and redesign management practices to create operational efficiency. Historically, the efforts of individual hotels and corporations have focused on 'increasing revenues' and 'controlling costs'. In order to remain competitive as an asset class in the future, the industry needs a

Table 10: Events Impactıng on profits and operational efficiency in the future (2007 and 2027)

\begin{tabular}{|c|c|c|c|c|c|c|}
\hline & $\begin{array}{l}\text { Mean* } \\
2007\end{array}$ & $\begin{array}{l}\text { Median } \\
2007\end{array}$ & $\begin{array}{l}\text { Event } \\
\text { probability } \\
2007^{* *}(\%)\end{array}$ & $\begin{array}{l}\text { Mean* } \\
2027\end{array}$ & $\begin{array}{l}\text { Median } \\
2027\end{array}$ & $\begin{array}{l}\text { Event } \\
\text { probability } \\
2027^{* *}(\%)\end{array}$ \\
\hline $\begin{array}{l}\text { The cost of payroll taxes and } \\
\text { employee benefits will be higher }\end{array}$ & 4.4 & 4.0 & 92 & 4.4 & 4.5 & 92 \\
\hline $\begin{array}{l}\text { Labour will continue to remain } \\
\text { one of the highest cost factors }\end{array}$ & 4.3 & 4.0 & 92 & 4.1 & 4.0 & 84 \\
\hline $\begin{array}{l}\text { Pervasive use of cellphones will } \\
\text { turn the telecommunications } \\
\text { department into a cost centre } \\
\text { rather than a profit centre }\end{array}$ & 4.2 & 4.0 & 85 & 4.3 & 5.0 & 84 \\
\hline $\begin{array}{l}\text { Terrorism insurance coverage } \\
\text { will be the norm for large hotels } \\
\text { in metropolitan areas }\end{array}$ & 3.7 & 4.0 & 59 & 3.5 & 3.0 & 48 \\
\hline $\begin{array}{l}\text { With rapidly changing technology, } \\
\text { leasing will be a popular source } \\
\text { of financing capital expenditure } \\
\text { items }\end{array}$ & 3.6 & 4.0 & 54 & 3.6 & 3.0 & 48 \\
\hline
\end{tabular}

Scale: 5 = Very likely to occur; $1=$ Not at all likely to occur

${ }^{* *}$ Cumulative percentage of 'Very likely to occur (5)' and 'Likely to occur (4)' 


\section{Ossification of hotel operational practices}

\section{Tougher lending environment in the future}

comprehensive evaluation of business practices for creating more predictable revenue flows and crafting revolutionary cost structures to reduce and eliminate certain costs.

For the past 20 years hotel payroll and related costs have varied narrowly between 31 and 35 per cent. Based on panel predictions these costs are expected to remain one of the highest operational costs in the future. If one were to focus on just this fact alone, it is indicative of an ossification of operational practices in the hotel industry. On the revenue side, hotels have passively watched the increasing pervasiveness of cellphones 'eating into' their telephone revenues. While some of the leading hotel companies have belatedly reacted with various strategies to counteract the negative effects, it is yet another example of the industry being slow to react to external events that impact on net profits. It is no wonder that the panellists predicted that telephone departments will become cost centres in the future. Various other revenue and cost factors similarly have not structurally changed in the industry for some time.

While other factors may have contributed to this systemic inertia, a partial explanation is the non-alignment of the goals of management and ownership. With their initial introduction in the 1970s, management companies which operate hotels and earn their revenues based on fee income have focused largely on increasing revenue and, when linked with a brand, maintaining brand value. These goals may or may not be aligned with an investor who evaluates the attractiveness of an investment either on its prospect for increasing total returns (income and appreciation of value) or providing diversification benefits.

This misalignment has been partially corrected with the introduction of the professional asset manager, whose role was to provide oversight of both operations and the strategic management of the investment. ${ }^{45}$ From the perspective of the hotel investor and the ability of the industry to attract investment capital to the industry, this role may have to be expanded to include that of a 'change agent', introducing and influencing innovative operational practices and creating investment structures to optimise real estate portfolios. The authors recommend that investor/owner interest groups such as the Hotel Asset Managers Association (HAMA) and others allocate resources to investigate these practices in the future. With the increasing presence of the institutional real estate owner and the growth of publicly held real estate companies, the need for research in this area is expected to grow.

On the debt side of capital to the industry, two significant and related predictions are tougher lending terms and the increasing role of investment banks in providing capital in the future. Both these predictions point towards stronger underwriting standards, and consequently a flow of more 'disciplined' capital to the hotel industry. With debt representing 60-70 per cent of the total capital for a hotel investment, if this prediction holds true it will smoothen 
the boom-bust cycles associated with past periods. Critical to the underwriting process will be the role of the feasibility study in projecting hotel income. In a recent study in which community bankers were asked their views on hotel feasibility studies, most expressed dissatisfaction with parts of the report that are critical to making lending decisions. The five factors identified by bankers as crucial or very important to making lending decisions are financial strength of applicant, location of hotel, experience of sponsor, fit of project to the market and financial projections. ${ }^{46}$

Finally, the panellist predictions of more capital flowing to finance urban hotels and for renovations, upgrades and acquisitions are a positive signal for downtown redevelopment and improvement of the present quality of facilities.

\section{References}

1. Pyhrr, S A., Cooper, J. R., Wofford, L. E., Kapplin, S. D. and Lappides, P. D. (1989) Real Estate Investment, 2nd edn, John Wiley \& Sons, New York, NY.

2. Sinkley, J. F. (1992) Commercial Bank Financial Management, 4th edn, Macmillan, New York, NY.

3. Schmidgall, R. S. (2001) Hospitality Industry Managerial Accounting, 5th edn, Van Nostrand Reinhold, New York, NY.

4 Moeller, G. H. and Shafer, E. L. (1994) 'The Delphi technique: A tool for long range travel and tourısm plannıng', in Brent Ritchie, J. R. and Goeldner, C. R. (eds) Travel, Tourism and Hospitality Research A Handbook for Managers and Researchers, John Wiley \& Sons, New York, NY, pp. 473-480.

5. Helmer, O. and Rescher, N. (1960) 'On the epistemology of exact sciences', Rand Corporation Paper R353, Santa Monica, CA.

6. Linstone, H. A. and Turoff, M. (1979) The Delphi Method, Addıson Wesley, Reading, MA.

7. Palıwoda, S. J (1983) 'Predicting the future using Delphi', Managerıal Decisions, Vol. 21, No. 1, pp. 31-38.

8. Johnson, J. L. (1976) 'A ten-year forecast in the electronics industry', Industrial Marketing Management, Vol. 5, No 1, pp. 45-55.

9 Ibid.

10. Moeller and Shafer, ref. 4 above.

11. Martino, J P (1983) Technological Forecasting for Decision Making, North Holland. New York, NY.

12 Deveau, L. T. (1994) 'Doctoral programs in hospitality administration: A Delphı study', doctoral dissertation, University of Bridgeport, Bridgeport, CT.

13. Linstone and Turoff, ref. 6 above.

14. Tersine, R. J. and Riggs, W. E. (1976) 'The Delphi technique: A long range planning tool', Business Horizons, April, pp. 51-56.

15. Ostroff, A. J. and Toman, A. (1995) 'Hotel investment and risk analysis', in Raleigh, L. E. and Roginsky, R. J. (eds) Hotel Investments Issues and Perspectives, Educational Institute, East Lansing, MI, pp. 23-53.

16. Lend Lease (2003) Emerging Trends in Real Estate, Lend Lease Real Estate Investments and PricewaterhouseCoopers, New York, NY.

17. Viezer, T. W. (2000) 'Evaluating "within real estate" diversfication strategies', Journal of Real Estate Portfolio Management, Vol. 6, No. 1, pp. 75-95.

18. Quan, D. C., L1, J. and Sehgal, A. (2002) 'The performance of lodging properties in an investment portfolio', Cornell Hotel and Restaurant Administration Quarterly, Vol. 43, No. 6, pp. 81-89.

19. National Council of Real Estate Investment Fiducianes, avallable at www.ncreif.com. 
20. Petersen, G. A. and Singh, A. J. (2003) 'Performance of hotel investment in a mult1property commercial real estate portfolio: Analysis of results from 1982 to 2001', Journal of Retail and Leisure Property, Vol. 3, No 2, pp 158-175

21. Guerra, J. E. (2004) 'The Sarbanes-Oxley Act and the evolution of corporate governance', CPA Journal, Vol 74, No 4, pp. 10-12.

22. Malley, M. (2002) 'Best practices in corporate governance lacking', Hotel and Motel Management, Vol. 217, No. 15, p. 8

23. Belmonte, S. J. (2003) 'Shinung light on little-known new law', Lodging Hospitalty, Vol. 59 , No. 59, p. 26.

24. Chakarun, M. (2002) 'The Sarbanes Oxley Act of 2002', Natıonal Public Accountant, October, pp. 6-10.

25. Kefgen, K. (2004) 'Board scrutiny a fact of public life', Hotel Business, 21 September, pp. available at www.hvsinternational.com/staticcontent/library/2004-0928-000.aspx

26. Mile, M. E., Berens, G. and Weiss, M. A. (2000) Real Estate Development Principles and Process, 3rd edn, Urban Land Institute, Washington, DC.

27 Lend Lease, ref. 16 above.

28 Bergsman, S (1997) 'Carving out a new asset class', Investment Dealers Digest. 1 December, pp. 14-27.

29. Hanson, B. and Smith, R. A. (2003) 'Overview of the lodging industry', in Raleigh, L. E. and Roginsky, R. J. (eds) Hotel Investments Issues and Perspectives, Educational Institute, East Lansing, MI, pp. 1-37.

30. Singh, A J. (2004) 'The securitization of US lodging real estate finance: The development and evolution of commercial mortgage backed securities', FIU Hospitality Review, Vol. 21, No. 2, pp. 69-80.

31. Urban Land Institute (2004) Real Estate Capital Market Update, 30 September, Vol 6 , No. 16, available at www.uli org.

32. Ibid.

33. Singh, A. J. (1999) 'A 20th century history and Delph1 study to predict changes in the lodging industry structure, performance and capital sources', doctoral dissertation, Michigan State Unıversity, East Lansing, MI.

34 Hanson and Smith, ref. 29 above.

35. Ibid.

36. Ibid

37. Pannell Kerr Forster (2003) Trends in the Hotel Industry, USA Edition, Hospitality Asset Advisors International, CA

38. Based on ibıd., the total cost of salaries and meals in US hotels is currently 43.7 per cent of total costs and expenses.

39. Kasavana, M. and Singh, A. J. (2004) 'Delphı study to predict key technological events in 2007 and 2027', manuscript in progress.

40. Vallen, G. K. and Vallen, J. J (2005) Check-In Check-Out, 7th edn, Pearson Prentıce Hall, Upper Saddle River, NJ.

41. Pannell Kerr Forster, ref. 37 above.

42. Forrester Research (2004) 'Benchmark data overview, fourth quarter 2004', avalable at www.forrester.com.

43 Gunter, H. (2004) 'Overall insurance costs decrease', Hotel and Motel Management, Vol. 219, No. 15, pp. 1-2.

44. Pozzi, S R. (2004) 'Terrorism: The new 21st century CAT', National Underwriter P\&C, Vol. 108. No. 33, pp. 27-29

45. Beals, $\mathbf{P}$ (2004) 'The history of hotel asset management', in Beals, P. and Denton, $\mathrm{G}$ (eds) Hotel Asset Management Principles and Practices, Educational Institute, East Lansing, MI, pp. 3-14.

46. Singh, A. J., Schmidgall, R S. and Beals, P. (2004) 'A survey of community banker attitudes toward hotel feasibility studies', RMA Journal, Vol. 86, No 7, pp. 28-35. 